\title{
Measuring Urban Form Units: Alternative for Characterizing Urban Growth Pattern in Yogyakarta Urbanized Areas
}

\author{
${ }^{1}$ Mutiasari Kurnia Devi, ${ }^{1}$ Lulu Mari Fitria, ${ }^{2} \mathrm{M}$. Sani Roychansyah and ${ }^{2}$ Yori Herwangi \\ ${ }^{1}$ Urban and Regional Planning Department, Institut Teknologi Nasional Yogyakarta \\ ${ }^{2}$ Architecture and Planning Department, Universitas Gadjah Mada, Indonesia
}

Received: 2019-02-01 Accepted: $2020-05-28$

Keywords: urban form; urban growth; agglomeration

Correspondent email: mutiasari@sttnas.ac.id

\begin{abstract}
Yogyakarta is one of city in Indonesia which experience urban agglomeration called by Yogyakarta Urbanized Area (YUA). In this paper, we identified the characters of each part of YUA by examining its urban form unit. This paper assesses the characteristics of urban forms distributed within YUA. Quantitative measurements were proposed for classifying the urban form typologies. Density, diversity, and accessibility were used to represent the urban form characteristic. The typologies are classified into three groups which are low compact, middle compact, and high compact. The result shows that the majority areas in YUA are grouped into middle compact typology where most of them are located in the city of Yogyakarta administrative area. Meanwhile, the areas, categorized as low compact typology, are in the hinterland area of Yogyakarta. High compact typology are concentrated in the centre of YUA where it has the highest activity concentration for the whole urban structure context. This study discovers that characterizing the urban growth patterns using quantitative method can distinguish urban form. At the end, this paper provides an important note about the distribution of urban form typology in the agglomeration area and, in the future, can be used to design urban policies, especially in the utilization of urban space.
\end{abstract}

2020 by the authors. Licensee Indonesian Journal of Geography, Indonesia.

Titions of the Creative Commons

Attribution(CC BY NC) licensehttps://creativecommons.org/licenses/by-nc/4.0/.

\section{Introduction}

The majority of world's populations are predicted to live in cities. By 2030 , nearly $60 \%$ of world population will live in cities (UNFPA, 2007). Drawing insights from this fact, many cities, especially in developing countries, will experience urbanisation at large scale, however, at the same time the urban infrastructure has not been able to accommodate the population. According to Statista (Statista, 2017), about 55\% of Indonesia population live in urban area. In 2010, the urban population was about $50 \%$ and it went up to $53,5 \%$ in 2015 . This trends will be continuously increasing until 2035. It is predicted that the urban population will hit $60 \%$ by 2025 and will reach $63,4 \%$ by 2030 (BPS, 2013). It gives a clear image that the rapid growth of urban population and urbanization is happening in a large scale. Therefore, the growth of urban population requires serious attention from stakeholders, in particularly urban planners. Increasing population which followed by rapid urbanisation has important implications for urban area expansion. This implication yields urban agglomeration within surrounded areas as the consequence. Not only that, but also rapid urbanisation causes a wide range of urban problems, including urban sprawl.

Sprawl is often defined by four land use characteristics: low density; scattered development (i.e. decentralised sprawl); commercial strip development; and, leapfrog development (Ewing, 1997). It can be described as an overall low density development or a scattered or leapfrog development with a daily commuting of its people relying on automobile (Uhel, 2006 cited in Abrantes et al., 2019; Galster et al., 2001; Kasanko et al., 2006). Higher environmental impacts are reported to be associated with low densities, one of sprawl development characteristics (Camagni, Cristina, \& Rigamonti, 2002). In line with previous findings, Nechyba \& Walsh (2004) mentioned that sprawl can be linked to environmental issues as lower-density development. In other words, sprawl can be associated as the increase in emissions per mile travelled related to traffic congestion and the increases in vehicle miles travelled. Urban sprawl also leads to cause loss of productive agricultural lands, open green spaces, as well as loss of surface water bodies (Bhat, Shafiq, Mir, \& Ahmed, 2017). In addition to that, social sector is also reported to have negatively affected by urban sprawl. People who live farther from each other will have weak linkages within neighbours (Burchell et al., 1998 cited in (Nguyen, 2010) as well as social segregation (Camagni and Gibelli, 1997 cited in (Camagni et al., 2002)).

Handy (1996) defines urban form as a composite of characteristics related to land use patterns, transportation system, and urban design. Urban form can be further described conceptually as the spatial pattern of human activities including the physical configuration of a city along with land use patterns, population and housing densities, infrastructure and amenities, and transport and communication networks (Anderson et al., 1996 cited in (Tsai, 2005); Abrantes et al., 2019). In term of geographical scales, urban form can be viewed and classified into several levels, such as metropolitan area, city, and even neighbourhood. The reason for this classification is twofold. First, some urban form variables operate only at certain 
levels, such as the job-housing balance variable. Secondly, urban form variables (such as density) may carry different meanings at different levels and may differently affect human activities, such as travel behaviour (Tsai, 2005). To sum up the concept of urban form, urban form is a result of the bringing together of many elements-concepts: the urban pattern (Jabareen, 2006).

Longstanding attempts to quantify urban sprawl that focuses on the growth of suburbs relative to central cities in which showing that suburbs have grown more rapidly than the central cities they surround (Chinitz, 1969). Song \& Knaap (2004) measures urban form by utilizing street design and circulation systems, density, land use mix, accessibility, and pedestrian access to evaluate the development patterns in Portland, Oregon. Meanwhile, Tsai (2005) describes urban form by using three categories which are density, diversity, and spatial-structure pattern. In contrast, Chin (2002) points out three principal dimensions of urban sprawl such as urban spatial scale, population density decline, and scattered urbanisation. Among several variables that have been used to identify urban form, population density and land use cover are the key variables to explain more depth the typology of urban areas (Abrantes et al., 2019).

Sustainable urban forms have been a concern in the context of developed cities which described as "new urbanism" or the "compact city" (Abe \& Kato, 2017). As urban sprawl triggers many negative implications towards environment, social, and economic, there is a vision for many urban planners in the $21^{\text {st }}$ century to create places with more compact design, more accessible to public transportation, and less driving.The key principles which are proposed in order to create more sustainable urban form, are promoting walkability and connectivity, mixed land uses, and high density (Rukmana, 2018). Newman \& Kenworthy (2000) found that the compact city emerges as the most fuel-efficient of urban forms. They conclude that urban form matters to improve urban air quality. Compactness also does not have a generally accepted definitions. Gordon \& Richardson (1996) potray compactness as high-density or monocentric development. Ewing's definition (Ewing, 1997) was some concentration of employment and housing, as well as some mixture of land uses. Alternatively, Anderson et al. (Anderson, Kanaroglou, \& Miller, 1996) defined both monocentric and polycentric forms as being compact. To conclude the definition, compactness refers to urban continuity (and connectivity), which suggest that future urban development shall take place adjacent to existing urban structures (Wheeler, 2002) as compactness brings the concentration of development (Tsai, 2005).

The studies on urban form have been drawing interests in international research area for the past decades. However, in Indonesia context, the lack of theoretical and empirical works to address urban structure using quantitative measures is still underdeveloped. In fact, understanding urban form can lead to better decisions on urban transportation, growth strategy, as well as the development of infrastructure (Bin Kashem, Chowdhury, Majumder, \& Rahman, 2009). In recent years, a number of quantitative variables have been developed to characterise urban sprawl. However, there are some gaps in the definitions of compactness and sprawl, and in the appropriate quantitative variables. This paper aims to characterise quantitatively urban form in general and to distinguish compactness from sprawl particularly using urbanized area case. The findings can be taken to propose different types of urban policies and planning approaches based on the urban form typology as well as to attain sustainable travel. Moreover, by measuring the urban form unit, we can also reveal the trends of urban development in YUA context. The study starts with a literature review of definitions of urban form and definitions of compactness and sprawl. After that, the different dimensions of metropolitan forms, accompanied with appropriate quantitative indexes in which the degrees of compactness and sprawl are revealed.

\section{The Methods \\ Site Study}

In terms of area coverage, this study was conducted in Yogyakarta Urbanized Area (YUA) with the object of research is the built environment, particularly urban form characteristic in that location. YUA covers 14 (fourteen) subdistricts in Yogyakarta City, 6 (six) sub-districts in Sleman Regency, and 3 (three) sub-districts in Bantul Regency.

\section{Data Sets and Analysis}

This paper developed a set of quantitative variables to characterise urban forms at the metropolitan level, and in particular, to distinguish compactness from "sprawl". The analysis follows reviewing and analysing former research on the definitions of urban form, compactness and sprawl, and corresponding quantitative variables. Density, diversity, and accessibility are often used to describe the urban form within region. Density is a critical typology in determining sustainable urban forms. It is the ratio of people or dwelling units to land area. Meanwhile diversity is a multidimensional phenomenon (Turner \& Murray, 2001) that promotes further desirable urban features, including greater varieties of housing types, building densities, household sizes, ages, cultures, and incomes. Thus, diversity represents the social and cultural context of the urban form. Sometimes diversity is being relates to the mixed used in which in this context mixed land use indicates the diversity of functional land uses such as residential, commercial, industrial, institutional, and those related to transportation.

There are several ways to categorize the typology of urban form. Jabareen (2006) classifies urban form into four different types such as neo-traditional, compact city, urban containment, and eco city. The typology is described through several criteria such as density, diversity, mixed land use, compactness, sustainable transportation, passive solar design, and greening ecological design. Using different perspective, Jackson-Smith et al. (Jackson-Smith et al., 2016) further clustered the urban form that have been linked to its water system characteristics. For this paper, we categorized the urban form typology into three categories based on the level of its compactness: low compact, middle compact, and high compact typology.

To represent density, diversity, and accessibility in deeper context, six quantitative variables were developed to measure six dimensions of urban form: population density, richness index, bus service coverage area index, number of transit stops, built-area ratio, and land use variation. The data sets are display on the Table 1 below.

The public transport service in Yogyakarta Special Province can be categorized into 4 type of services which are public transport (city bus and TransJogja), ojek, taxi, and non 


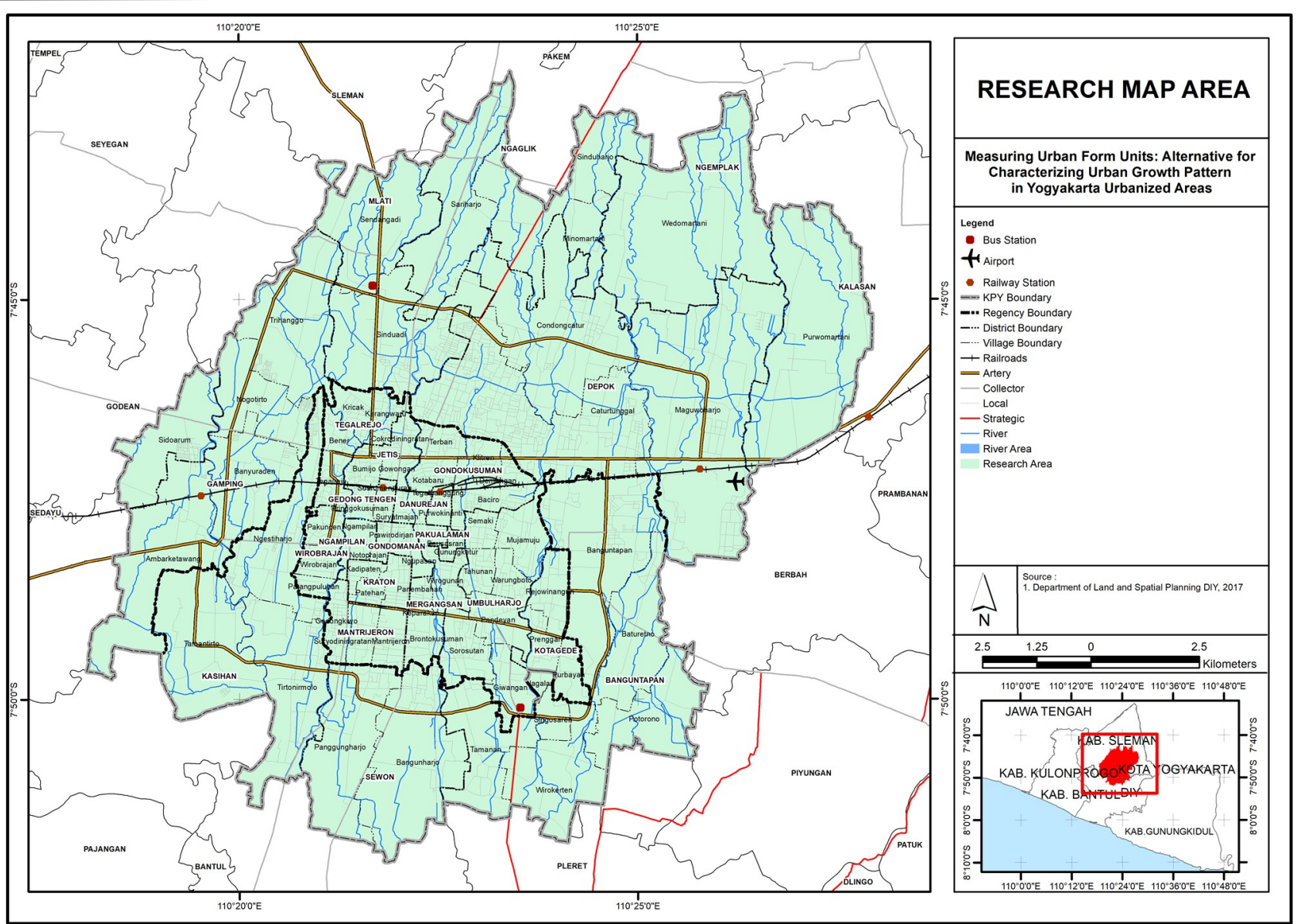

Figure 1. Research Area

Table 1. Data Sets

\begin{tabular}{ll}
\hline \multicolumn{1}{c}{ Variable } & \multicolumn{1}{c}{ Operational } \\
$\begin{array}{l}\text { DENSITY } \\
\begin{array}{l}\text { Population density } \\
\text { Built up area percentage }\end{array}\end{array}$ & $\begin{array}{l}\text { Total person per ha within the area } \\
\text { Total built up area per total area }\end{array}$ \\
$\begin{array}{l}\text { DIVERSITY } \\
\text { Richness Index }\end{array}$ & Ratio of its total land use groups \\
Land use variation & Ratio of non-residential area per total area of its residential area \\
$\begin{array}{l}\text { ACCESSIBILITY } \\
\text { Number of transit stop } \\
\text { Bus service coverage ratio }\end{array}$ & $\begin{array}{l}\text { Total transit stops of TransJogja within the area } \\
\text { Ratio between the length of TransJogja routes and total length of road } \\
\text { within the area }\end{array}$ \\
\hline
\end{tabular}

Source: Analysis, 2018

-motorized transportation (becak and andhong). TransJogja is expected to be the most reliable public transport services in Yogyakarta area which classified as Bus Rapid Transit (BRT) system. Accessibility towards public transportation service was measured through calculating the bus service coverage rate (BSCR) as the ratio between the length of TransJogja routes and total length of road. To represent the public transport service level in all Yogyakarta urbanized area, we divided the value of BSCR into three categories: low bus service coverage ratio (BSCR $=<0,1$ ); middle bus service coverage ratio (BSCR $=0,1-0,3$ ); high bus service coverage ratio $(\mathrm{BSCR}=>0,3)$.

After we collecting the values of six variables, we classified the region into three categories which are low, middle, and high based on the interval class within the value. The classification of six variables in this study is shown in Table 2. The values of these variables were averaged and used to divide the urban forms into three domains (high compact, middle compact and low compact). High compact has high value of density, diversity and accessibility, whilst medium compact and low compact have medium and low value of these three factors accordingly.

\section{Result and Discussion \\ Land Use Characteristics}


Table 2. Interval Value Classification between Variables

\begin{tabular}{lcccccc}
\hline Interval Class & $\begin{array}{c}\text { Population } \\
\text { density }\end{array}$ & $\begin{array}{c}\text { Built-up area } \\
\text { percentage }\end{array}$ & $\begin{array}{c}\text { Richness in- } \\
\text { dex }\end{array}$ & $\begin{array}{c}\text { Land use varia- } \\
\text { tion }\end{array}$ & $\begin{array}{c}\text { Number of } \\
\text { transit stop }\end{array}$ & $\begin{array}{c}\text { Bus service } \\
\text { coverage area }\end{array}$ \\
\hline Low & $<45$ & $<68$ & $<0,33$ & 0 & $<1$ & $<0,1$ \\
Middle & $45-149$ & $68-97$ & $0,33-0,67$ & $0-0,045$ & $1-5$ & $0,1-0,3$ \\
High & $>149$ & $>97$ & $>0,67$ & $>0,045$ & $>5$ & $>0,3$ \\
\hline
\end{tabular}

Source: Analysis, 2018

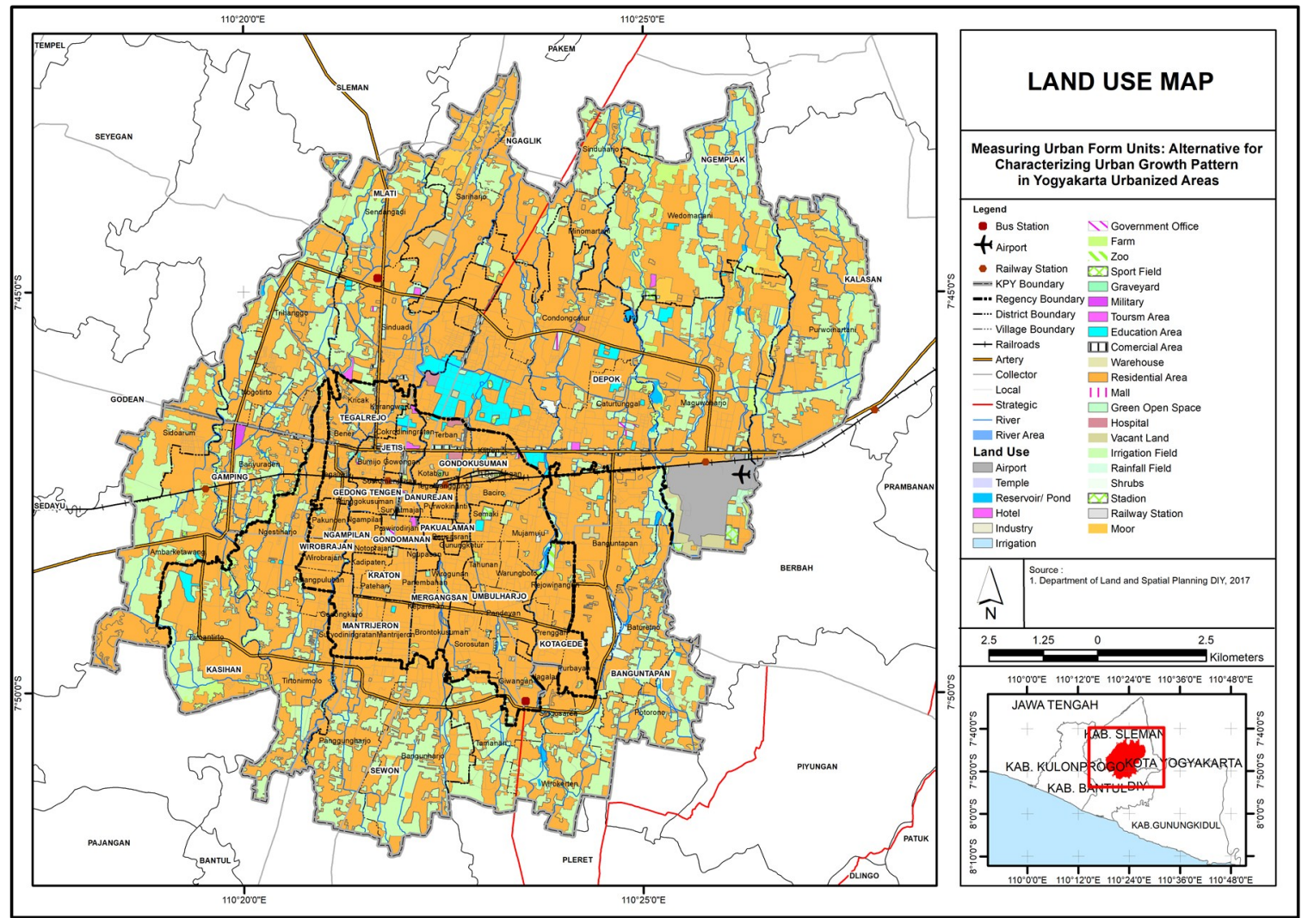

Figure 2. Land Use Map

DIY Agriculture Office (BPS, 2016) states that the conversion of agricultural land in DIY reaches 200 - $250 \mathrm{Ha}$ per year, where most of it occurs in urban and periphery areas. In the city of Yogyakarta, agricultural land is only 56 hectares or only around $2 \%$ of the total city area of 3,250 ha. Subsequent land use in YUA is $5.14 \%$ of dry land / gardens / fields / yards, riverbanks in YUA reaches $4.17 \%$, and the remaining $5.48 \%$ for other sectors such as education, trade and services, Public facilities, green open spaces, ponds / ponds and so on. Having this on mind, most of the area is dominated by densely populated residential areas in the central part of the city, while in the outer border (periphery) agricultural land remains stable as display on the Figure 2.

Looking at the land use distribution patterns in YUA, several lands greatly impact the patterns of community travel, namely settlements, offices, education, shopping centres, and trade and services. In the context of residential, it takes $66,37 \%$ of the total area of YUA. Mainly this residential area is centrally located in the centre of YUA since the region has good accessibility for transportation and public facilities.

\section{Commercial Activity Characteristics}

Yogyakarta Urban Growth follows a concentric pattern, where the City of Yogyakarta acts as a centres of growth. Growth centres for trade activities and services are developed from Jalan Malioboro to eastward (Jalan Solo) and partly to the north (Jalan Magelang). This development follows the city's growth and the improved road infrastructure. The centres for trading and economic activities in the Yogyakarta Urban Area occur by following the arterial and collector roads. Drawing idea from this, the total market is 175 markets, of which 27 markets are in Yogyakarta City, 8 markets are in the Bantul Regency, and as many as 140 markets are in Sleman Regency. In addition to the market presence, the trade sector is also dominated by 1777 shops, of which 890 shops are in Sleman Regency, 692 stores are in Yogyakarta City, and 195 stores are in Bantul Regency.

The number of hotels in Yogyakarta Urban Area is 306 buildings, of which 236 are in Yogyakarta City, 10 hotels are 
in Bantul Regency, and 60 hotels are in Sleman Regency. The most hotel facilities are in Gedong Tengen Subdistrict as many as 50 hotels, which are influenced by the Malioboro area as a tourism and trade centre of Yogyakarta City. The number of tertiary educational institutions in the city of Yogyakarta has reached 65. Meanwhile, the growth of education facilities is dominated by the northern region of the Yogyakarta Urban Area. The number of tertiary institutions in Sleman currently amounts to 30 private universities and 5 state universities.

\section{Urban Form Classification}

This section discusses the urban form classification through the measurement of density, diversity, and accessibility variable. In line with the aforementioned urban form variables, density is identified as population density and percentage of built-up area, diversity is identified as the Richness Index and variation in land use, and accessibility is identified as the number of public transport stops and ratio of coverage of public transportation services (Bus Service Coverage Rate/BSCR),

Results show that the majority of population density in YUA is still low. Figure 3 presents, high population density are concentrated in the centre of the area in which it is located in city of Yogyakarta administrative area. The activity concentration in which directed in the heart region of Yogyakarta can be related to high population density in this area. District of Danurejan, Gedongtengen, and Ngampilan are reported to have the highest density of population within YUA. The plausible reason to this finding is high concentration of residential in these areas. People are tend to reside closely to the public facilities. As the central government is located in Danurejan, this area provides good facilities, good connectivities, and many commercial activities which mostly people are looking for. Figure 3 also shows that high coverage of built-up area are also concentrated within centre area of YUA. Meanwhile, the suburban areas have low percentage of built-up area which means this area is still dominated by agricultural land use.

Table 3 describes the results of urban form typology within YUA. Most of the areas are categorized as middle compact typology characteristics, in which 13 areas are included in the low compact typology, 49 areas are included in the middle compact typology, and the remaining 9 areas are grouped in the high compact typology. Middle compact typology is dominated by region within city of Yogyakarta administrative area. Surprisingly, Bantul regency is not considered as high compact compare to the all parts of YUA. It is clear that multiple functions are often associated with higher densities and a greater mixed used activities. The lower its density values, the more scattering the activities as represent in the low compact area through its diversity value. In contrast, area with large variations of its activities have more compact urban form than areas with low variation have. Great accessibility in areas with large variation is inevitable.

Figure 4 describes high compact typology of urban form is concentrated in the centre of YUA. Caturtunggal and Sinduadi area, as a part of Sleman regency, are categorized as high compact areas. The existence of higher education within this area has triggered the emergence of new activities to support the function of the area. Rapid development in this area is also correlated with the higher densities as well as creating a multifunctional used within the area. Former research finds that Sleman regency is one of the areas where attracts people to come because of its function as the base for economy activities and as the base for educational facilities (Giyarsih, Arif, \& Alfana, 2013). It is indeed that Yogyakarta is experiencing the spatial expansion into its hinterlands and peripheries in order to accommodate the growing urban population along with urban activities.

Currently, the principal foundation for characterizing urban development and making urban comparisons is by

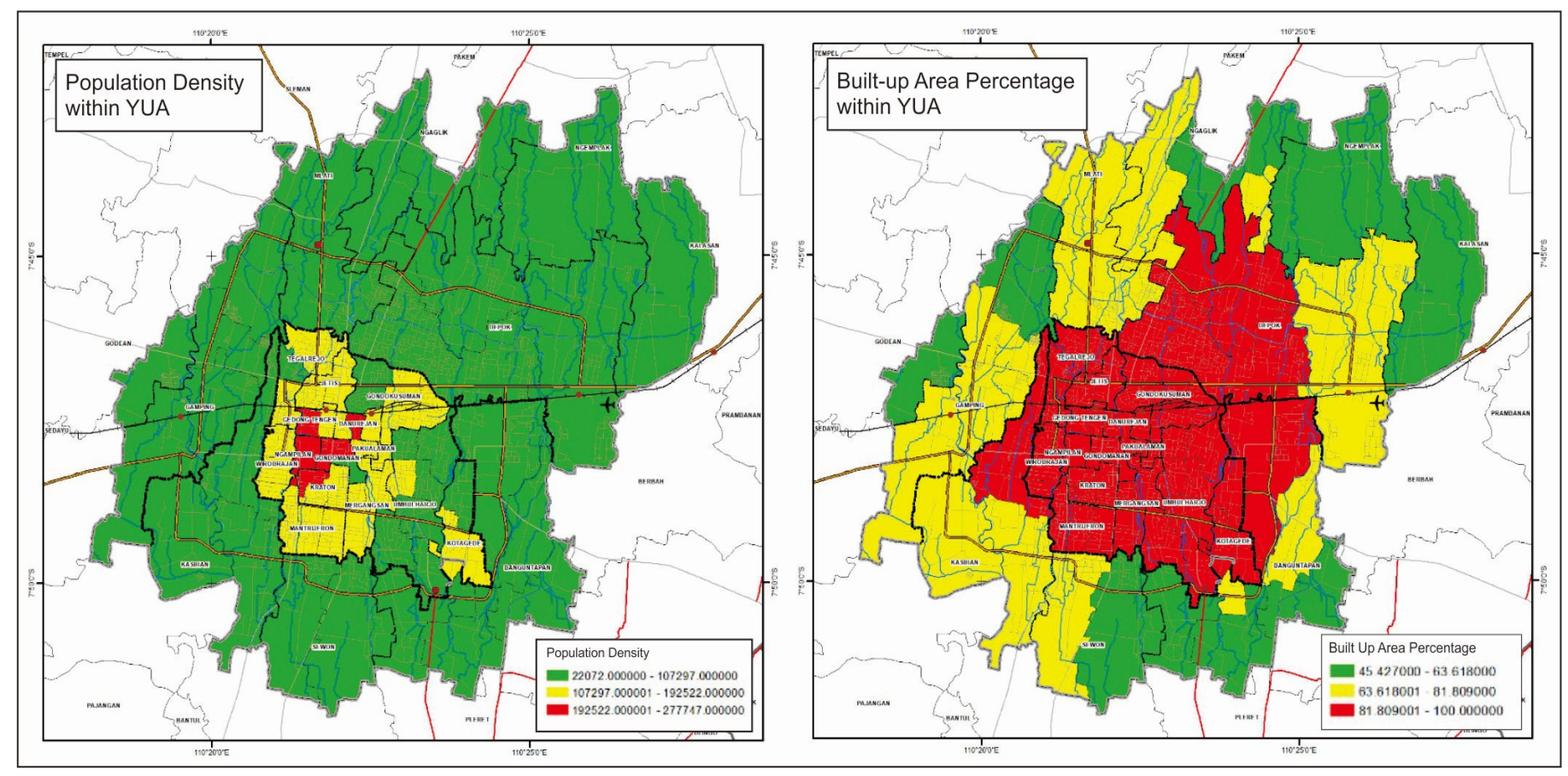

Figure 3. Density overview within YUA which seen through population and built-up area 
Table 3. Urban form classification in Yogyakarta Urbanized Area

\begin{tabular}{|c|c|c|c|c|c|c|c|c|}
\hline \multirow[b]{2}{*}{$\begin{array}{l}\text { Urban Form } \\
\text { Classification }\end{array}$} & \multirow[b]{2}{*}{$\begin{array}{l}\text { Kabupaten/ } \\
\text { Kota }\end{array}$} & \multirow[b]{2}{*}{ Desa/ Kelurahan } & \multicolumn{2}{|c|}{ DENSITY } & \multicolumn{2}{|c|}{ DIVERSITY } & \multicolumn{2}{|c|}{ ACCESIBILITY } \\
\hline & & & $\begin{array}{l}\text { Popula- } \\
\text { tion Den- } \\
\quad \text { sity }\end{array}$ & $\begin{array}{l}\% \text { Built- } \\
\text { up Area }\end{array}$ & $\begin{array}{l}\text { Richness } \\
\text { Index }\end{array}$ & $\begin{array}{l}\text { Land Use } \\
\text { Variation }\end{array}$ & $\begin{array}{c}\text { Transit } \\
\text { Stops }\end{array}$ & $\begin{array}{l}\text { Bus } \\
\text { Service } \\
\text { Coverage } \\
\text { Rate }\end{array}$ \\
\hline \multirow{3}{*}{$\begin{array}{l}\text { LOW COM- } \\
\text { PACT }\end{array}$} & $\begin{array}{l}\text { Yogyakarta } \\
\text { (3) }\end{array}$ & $\begin{array}{l}\text { Panembahan, Patehan, } \\
\text { Tahunan }\end{array}$ & 136,068 & 97,453 & 0,278 & 0 & 0,667 & 0,009 \\
\hline & Sleman (5) & $\begin{array}{l}\text { Sinduharjo, Minomar- } \\
\text { tani, Wedomartani, Si- } \\
\text { doarum, Purwomartani }\end{array}$ & 42,331 & 58,984 & 0,600 & 0,011 & 0 & 0,006 \\
\hline & Bantul (5) & $\begin{array}{l}\text { Wirokerten, Potorono, } \\
\text { Tamanan, Singosaren, } \\
\text { Bangunharjo }\end{array}$ & 40,830 & 53,883 & 0,333 & 0 & 1,400 & 0,055 \\
\hline \multirow[t]{3}{*}{$\begin{array}{l}\text { MIDDLE } \\
\text { COMPACT }\end{array}$} & $\begin{array}{l}\text { Yogyakarta } \\
(35)\end{array}$ & $\begin{array}{l}\text { Purbayan, Kadipaten, } \\
\text { Suryodiningratan, } \\
\text { Wirogunan, Bronto- } \\
\text { kusuman, Wirobrajan, } \\
\text { Keparakan, Bener, } \\
\text { Warungboto, Sorosutan, } \\
\text { Pakuncen, Prawirodir- } \\
\text { jan, Rejowinangun, } \\
\text { Gedongkiwo, } \\
\text { Gunungketur, Tegalrejo, } \\
\text { Karangwaru, Pandeyan, } \\
\text { Semaki, Giwangan, Pa- } \\
\text { tangpuluhan, } \\
\text { Pringgokusuman, } \\
\text { Ngupasan, Prenggan, } \\
\text { Mantrijeron, Ngampilan, } \\
\text { Notoprajan, Kricak, Mu- } \\
\text { ja-Muju, Tegal } \\
\text { Panggung, Demangan, } \\
\text { Baciro, Kotabaru, } \\
\text { Cokrodiningratan, Pur- } \\
\text { wokinanti }\end{array}$ & 137,251 & 95,104 & 0,429 & 0,034 & 3,114 & 0,253 \\
\hline & Sleman (5) & $\begin{array}{l}\text { Sariharjo, Nogotirto, } \\
\text { Banyuraden, Maguwo- } \\
\text { harjo, Condongcatur }\end{array}$ & 36,945 & 66,919 & 0,646 & 0,067 & 3,875 & 0,148 \\
\hline & Bantul (9) & $\begin{array}{l}\text { Panggungharjo, Ba- } \\
\text { turetno, Tirtonirmolo, } \\
\text { Sendangadi, Trihanggo, } \\
\text { Ambarketawang, Ngesti- } \\
\text { harjo, Tamantirto, } \\
\text { Banguntapan }\end{array}$ & 60,161 & 72,668 & 0,556 & 0,013 & 5 & 0,154 \\
\hline \multirow{3}{*}{$\begin{array}{l}\text { HIGH } \\
\text { COMPACT }\end{array}$} & $\begin{array}{l}\text { Yogyakarta } \\
\text { (7) }\end{array}$ & $\begin{array}{l}\text { Klitren, Bumijo, Gowon- } \\
\text { gan, Suryatmajan, } \\
\text { Bausasran, Sosromen- } \\
\text { duran, Terban }\end{array}$ & 153,785 & 97,453 & 0,690 & 0,234 & 3 & 0,399 \\
\hline & Sleman (2) & Caturtunggal, Sinduadi & 48,913 & 85,583 & 1 & 0,224 & 25 & 0,196 \\
\hline & Bantul (0) & - & & & & & & \\
\hline
\end{tabular}




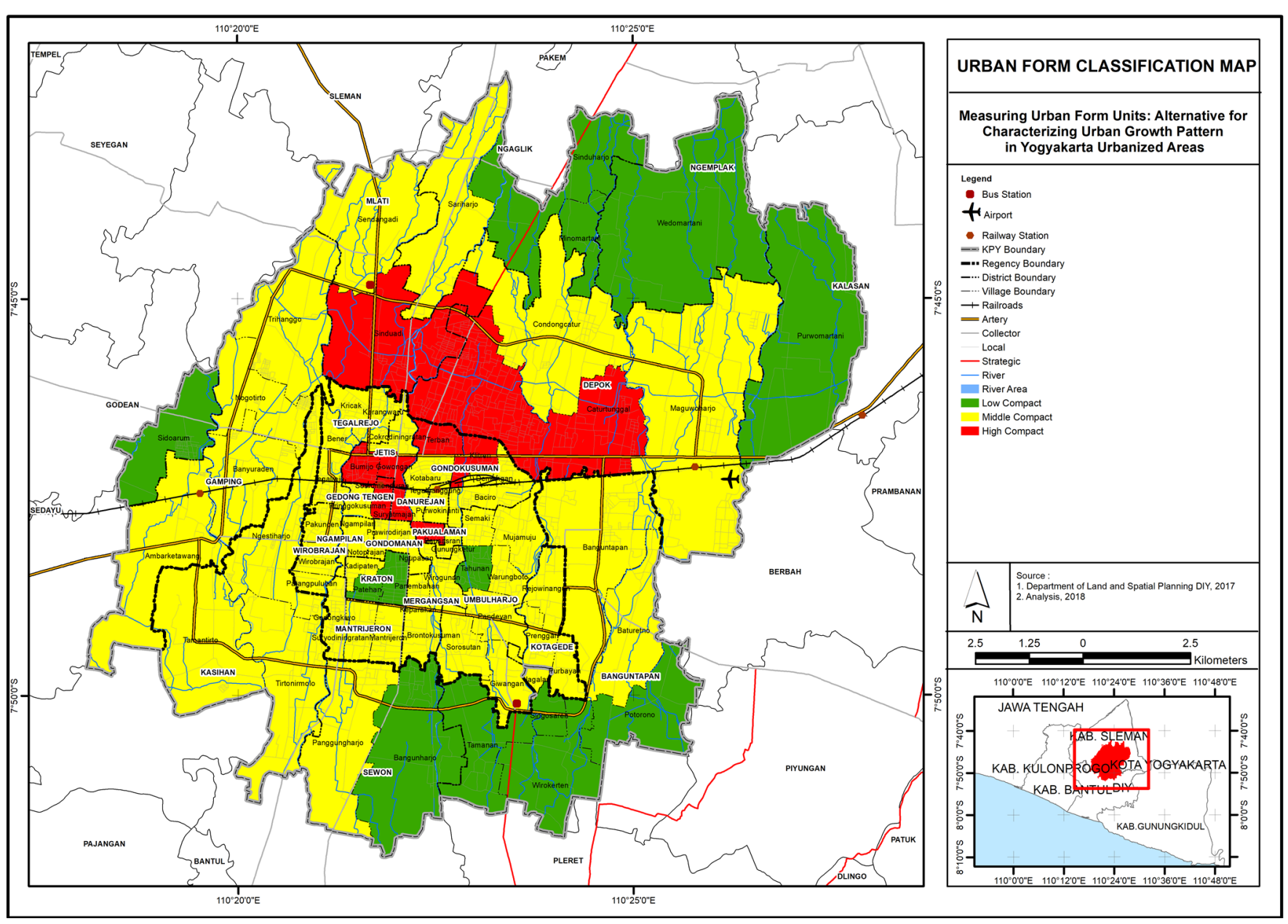

Figure 4. Classification of urban form typology in Yogyakarta Urbanized Area

using demographic-measure city population size (Stokes \& Seto, 2019). Yuan et al. (Yuan, Song, Huang, Hong, \& Huang, 2018) evaluate urban forms with six multiple dimensions which are population density, degree of centralization, mixed land use, street accessibility, shape complexity, and urban continuity. In the context of methodology approach, many studies use GIS and remote sensing methods to quantify and describe urban growth model (Almdhun, Mallak, Aburas, Md Said, \& Ghadiri, 2018; Jiao, 2015; Shi, Sun, Zhu, Li, \& Mei, 2012). Moreover, former study using Dublin city as the case study measures urban form changes by analysing street network design, land use mix, and density in community scale applying GIS functions (Nedovic-Budic, Knaap, Shahumyan, Williams, \& Slaev, 2016). This study enriches the findings in characterizing urban expansion by using combination of variables in density, diversity, and accessibility. Results from this study confirm previous findings that urban expansion happens in a large scale. However, the expansion that is associated with sprawl in which characterized by low density, diversity, and accessibility in suburban area while the high concentration of activities is located in urban centre area. This high concentration of activities is associated with higher level of compactness which measured through its density, diversity, and accessibility.

\section{Conclusion}

This paper gives brief understanding on how to define urban form unit in the urban areas by quantifying the variables. The measurements of urban form units can be used to investigate other sustainability issues, particularly in transportation issues and quality of life. Therefore, this study can contribute significantly to the debate on building sustainable urban form in developing countries.

The major findings are summarized as, first, the urban growth of YUA is concentrated in the centre of YUA which shown through the characteristic of its high compact urban form. Another finding is, the agglomeration in the context of YUA mostly happen in Sleman regency which located in the north of the area. Although Sleman regency is considered as high compact area, higher education activities are the trigger to the emergence of rapid development within surrounded area. Last but not least, the majority of the area in YUA is classified as middle compact typology where most of them is in the city of Yogyakarta administrative area. Meanwhile, the area which categorized as low compact typology are located in the hinterland area of Yogyakarta. In the low compact and middle compact area, there should be policies to increase multifunctional use and accessibility within area in order to create more compact area development and sustainable urban form.

It is indeed that the indicators described in the paper have numbers of drawbacks that need to be taken into account for further development of this empirical work. Moreover, there is also the opportunity to improve the methods for clustering the urban form typology as in this paper we used the basic 
statistical value in grouping the typology.

\section{Acknowledgement}

This research was fully funded by the Minister of Research, Technology, and Higher Education of Republic Indonesia, contract number 03.b/STTNAS/P3M/Pen.DRPM/ III/2018.

\section{References}

Abe, R., \& Kato, H. (2017). Built Environment, Travel, and Residential Satisfaction in a Developing City: Can Residents under Rapid Urbanization Agree with a Sustainable Urban Form? Asian Transport Studies, 4(3), 481-498. https:// doi.org/10.11175/eastsats.4.481

Abrantes, P., Rocha, J., Marques da Costa, E., Gomes, E., Morgado, P., \& Costa, N. (2019). Modelling urban form: A multidimensional typology of urban occupation for spatial analysis. Environment and Planning B: Urban Analytics and City Science, 46(1), 47-65. https:// doi.org/10.1177/2399808317700140

Almdhun, H. M., Mallak, S. K., Aburas, M. M., Md Said, M. A., \& Ghadiri, S. M. (2018). Measuring and predicting urban growth patterns and trends in Putrajaya, Malaysia. IOP Conference Series: Earth and Environmental Science, 169(1). https://doi.org/10.1088/1755-1315/169/1/012114

Anderson, W. P., Kanaroglou, P. S., \& Miller, E. J. (1996). Urban Form, Energy and the Environment: A Review of Issues, Evidence and Policy. Urban Studies, 33(1), 7-35. https:// doi.org/10.1080/00420989650012095

Bhat, P. A., Shafiq, M. ul, Mir, A. A., \& Ahmed, P. (2017). Urban sprawl and its impact on landuse/land cover dynamics of Dehradun City, India. International Journal of Sustainable Built Environment, 6(2), 513-521. https://doi.org/10.1016/ j.ijsbe.2017.10.003

Bin Kashem, M. S., Chowdhury, T. A., Majumder, J., \& Rahman, M A. (2009). Quantifying Urban form: A Case Study of Rajshahi City. Journal of Bangladesh Institute of Planners, 2 (December), 39-48. https://doi.org/10.3329/jbip.v2i0.9555

BPS. (2013). Proyeksi Penduduk Indonesia 2010-2035. In Badan Pusat Statistik. Jakarta.

BPS. (2016). Statistik Daerah Istimewa Yogyakarta 2016. Provinsi DIY.

Camagni, R., Cristina, M., \& Rigamonti, P. (2002). Urban mobility and urban form: the social and environmental costs of different patterns of urban expansion. Ecological Economics, 40, 199-216. https://doi.org/10.1016/S0921-8009(01)00254-3

Chin, N. (2002). CENTRE FOR ADVANCED Working Paper Series METHODOLOGY. In Centre for Advanced Spatial Analysis, University College London.

Chinitz, B. (1969). The Regional Problem in the U.S.A. In R. E.A.G. (Ed.), Backward Areas in Advanced Countries, International Economic Association Conference Volumes. Springer.

Ewing, R. (1997). Is Los Angeles-Style Sprawl Desirable? Journal of the American Planning Association, 63(1), 107-126. https:// doi.org/10.1080/01944369708975728

Galster, G., Hanson, R., Ratcliffe, M. R., Wolman, H., Coleman, S., \& Freihage, J. (2001). Wrestling sprawl to the ground: Defining and measuring an elusive concept. Housing Policy Debate, 12(4), 681-717. https:// doi.org/10.1080/10511482.2001.9521426

Giyarsih, S. R., Arif, M., \& Alfana, F. (2013). the Role of Urban Area As the Determinant Factor of Population Growth Indonesian Journal of Geography, 45(1), 38-47. https:// doi.org/10.22146/indo.j.geog,2405

Gordon, P., \& Richardson, H. W. (1996). Employment decentralization in US metropolitan areas: Is Los Angeles an outlier or the norm? Environment and Planning A, 28(10), 1727-1743. https://doi.org/10.1068/a281727

Handy, S. (1996). Methodologies for exploring the link between urban form and travel behavior. Transportation Research Part D: Transport and Environment, 1(2), 151-165. https:// doi.org/10.1016/S1361-9209(96)00010-7

Jabareen, Y. R. (2006). Sustainable urban forms: Their typologies, models, and concepts. Journal of Planning Education and Research, 26(1), 38-52. https:// doi.org/10.1177/0739456X05285119

Jackson-Smith, D., Stoker, P., Buchert, M., Endter-Wada, J., Licon, C., Cannon, M., ... Bell, L. (2016). Differentiating Urban Forms: A Neighborhood Typology for Understanding Urban Water Systems. Cities and the Environment, 9(1), 5.

Jiao, L. (2015). Urban land density function: A new method to characterize urban expansion. Landscape and Urban Planning, 139, 26-39. https://doi.org/10.1016/ j.landurbplan.2015.02.017

Kasanko, M., Barredo, J. I., Lavalle, C., McCormick, N., Demicheli, L., Sagris, V., \& Brezger, A. (2006). Are European cities becoming dispersed?. A comparative analysis of 15 European urban areas. Landscape and Urban Planning, 77(1-2), 111130. https://doi.org/10.1016/j.landurbplan.2005.02.003

Nechyba, T. J., \& Walsh, R. P. (2004). Urban sprawl. Journal of Economic Perspectives, 18(4), 177-200. https:// doi.org/10.1257/0895330042632681

Nedovic-Budic, Z., Knaap, G. J., Shahumyan, H., Williams, B., \& Slaev, A. (2016). Measuring urban form at community scale: Case study of Dublin, Ireland. Cities, 55, 148-164. https:// doi.org/10.1016/j.cities.2016.02.014

Newman, P., \& Kenworthy, J. (2000). Sustainable Urban Form: The Big Picture. In K. Williams, E. Burton, \& M. Jenks (Eds.), Achieving Sustainable Urban Form. Taylor and Francis.

Nguyen, D. (2010). Evidence of the impacts of urban sprawl on social capital. Environment and Planning B: Planning and Design, 37(4), 610-627. https://doi.org/10.1068/b35120

Rukmana, D. (2018). Rapid urbanization and the need for sustainable transportation policies in Jakarta. IOP Conference Series: Earth and Environmental Science, 124(1). https://doi.org/10.1088/1755-1315/124/1/012017

Shi, Y., Sun, X., Zhu, X., Li, Y., \& Mei, L. (2012). Characterizing growth types and analyzing growth density distribution in response to urban growth patterns in peri-urban areas of Lianyungang City. Landscape and Urban Planning, 105(4), 425-433. https://doi.org/10.1016/j.landurbplan.2012.01.017

Song, Y., \& Knaap, G. J. (2004). Measuring urban form: Is portland winning the war on sprawl? Journal of the American Planning Association, 70(2), 210-225. https:// doi.org/10.1080/01944360408976371

Statista. (2017). Urbanization in Indonesia 2017. Retrieved November 18, 2018, from https://www.statista.com/ statistics/455835/urbanization-in-indonesia/

Stokes, E. C., \& Seto, K. C. (2019). Characterizing and measuring urban landscapes for sustainability. Environmental Research Letters, 14(4). https://doi.org/10.1088/1748-9326/aafab8

Tsai, Y. H. (2005). Quantifying urban form: Compactness versus "sprawl." Urban Studies, 42(1), 141-161. https:// doi.org/10.1080/0042098042000309748

Turner, R. S., \& Murray, M. S. (2001). Managing growth in a climate of urban diversity: South Florida's eastward ho! initiative. Journal of Planning Education and Research, 20(3), 308-328. https://doi.org/10.1177/0739456X0102000304

UNFPA. (2007). The State of the World Population 2007: Unleashing the potential of urban growth. UNFPA.

Wheeler, J. O. (2002). From urban economic to social/cultural urban geography, 1980-2001. Urban Geography, 23(2), 97102. https://doi.org/10.2747/0272-3638.23.2.97

Yuan, M., Song, Y., Huang, Y., Hong, S., \& Huang, L. (2018). Exploring the Association between Urban Form and Air Quality in China. Journal of Planning Education and Research, 38(4), 413-426. https:// doi.org/10.1177/0739456X17711516 